Alin Suciu

\title{
The Berlin-Strasbourg Apocryphon
}

\section{A Coptic Apostolic Memoir}

\author{
[Das Berlin-Straßburg Apokryphon . Ein koptisch-apostolisches Memoir.]
}

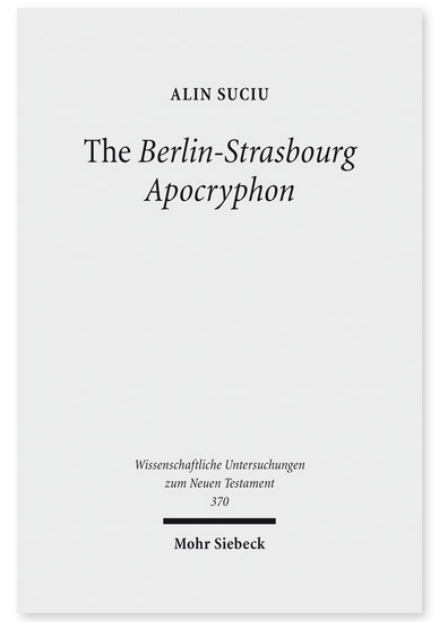

2017. XI, 241 Seiten. WUNT I 370

ISBN 978-3-16-155107-9

DOI 10.1628/978-3-16-155107-9

eBook PDF 114,00€

ISBN 978-3-16-155106-2

Leinen $114,00 €$
Veröffentlicht auf Englisch.

Die Unvollständigkeit, in der viele koptische Schriften überliefert sind, erschwert ihre Bewertung und der Text in diesem Band bildet hier keine Ausnahme. Das Berlin-Straßburg Apokryphon - vormals als Evangelium des Erlösers bekannt und in zwei fragmentarischen Handschriften erhalten - wurde fälschlicherweise für ein Evangelium aus dem zweiten Jahrhundert gehalten, welches bei der Zusammenstellung des christlichen Kanons übergangen wurde. Alin Suciu zeigt, dass die Missdeutung des Textes aus mangelhafter Kenntnis koptischer Literatur resultiert. Vielmehr ist das Berlin-Straßburg Apokryphon eines der zahlreichen »apostolischen Memoirs", einem besonderen Genre koptischer Literatur, welche aus Schriften bestand, die angeblich von den Aposteln verfasst wurden und Teil von Predigten berühmter Kirchenvätern sind. Diese Texte wurden nach dem Konzil von Chalcedon, als Teil der Bemühungen der neu entstehenden koptischen Kirche, ihre Identität nach dem Schisma zu festigen, geschrieben.

Inhaltsübersicht

Introduction

Chapter 1: History of Research on the Berlin-Strasbourg Apocryphon

A New Ancient Gospel? - Other Documents Emerge: The Strasbourg Fragments and the Qasr el-Wizz Codex - Reframing the Berlin-Strasbourg Apocryphon

\section{Chapter 2: The Manuscripts}

P. Berol. 22220

Location and Acquisition - Origin of P. Berol. 22220 - Paleography and Dating - Scribal Note - Codicology - Orthography

Strasbourg Copte 5-7

Location and Acquisition - Papyrological Reconstruction - Language - Paleography and Dating

The Qasr el-Wizz Codex

Discovery and Location - Content of the Codex - Description and Dating of the Manuscript

Chapter 3: The Content of the Berlin-Strasbourg Apocryphon and the Relationship between the Manuscripts Outline of the Text - The Relationship between the Manuscripts - The Relationship between P. Berol. 22220 and Strasbourg Copte 5-7 - The Relationship between the Strasbourg Fragments and the Qasr el-Wizz Manuscript - The Relationship between P. Berol. 22220 and the Qasr el-Wizz Manuscript - The Qasr el-Wizz Version of the Hymn of the Cross - Placing P. Berol. 22220 Frag. 9 - Placing Strasbourg Copte 6

Chapter 4: The Place of the Berlin-Strasbourg Apocryphon in Coptic Literature »We, the Apostles. "The Berlin-Strasbourg Apocryphon and Other Similar Coptic Stories Attributed to the Apostles - The Apostolic Memoirs Framed by a Patristic Sermon - The Apostolic Memoirs without a Homiletic Framework - 》O My Holy Members, « »O My Honored Members«: Apostles, Martyrs, and Monks - The Literary and Liturgical Function of the Coptic Memoirs of the Apostles - The Local Egyptian Character of the Apostolic Memoirs - Dating the Apostolic Memoirs - The Christology of the Berlin-Strasbourg Apocryphon : Christ as King and Son of the King. The Dating of the Work

Text and Translation

Edition of P. Berol. 22220 - Edition of Strasbourg Copte 5-7 - Edition of the Hymn of the Cross according to the Qasr el-Wizz Codex - Translation of P. Berol. 22220 - Translation of Strasbourg Copte 5-7 - Translation of the Hymn of the Cross according to the Qasr el-Wizz Codex

Alin Suciu Born 1978; 2013 PhD in Religious Studies from Université Laval, Québec; 2013-14 research fellow at the Hiob Ludolf Centre for Ethiopian Studies, Hamburg; since 2015 senior researcher at the Göttingen Academy of Sciences and Humanities.

Jetzt bestellen:

https://mohrsiebeck.com/buch/the-berlin-strasbourg-apocryphon-9783161551079?no_cache=1

order@mohrsiebeck.com

Telefon: $+49(0) 7071-923-17$

Telefax: $+49(0) 7071-51104$ 